\title{
Comparison between Pakistani Kashi Tiles and Persian Kashan Tiles
}

\author{
Qurat ul Ain \\ Nanjing University of Arts,No.74 Beijing West Road, Gulou District, Nanjing and 210013, China \\ Centre of excellence in Art and Design,MUET, Main Highway Road, opposite toll plaze, Jamshoro and 71800, Pakistan. \\ annie.bhayo@gmail.com
}

\section{ARTICLE INFO}

\section{Article history}

Received 2019-03-31

Revised 2019-06-08

Accepted 2019-05-25

\section{Keywords}

Kashi Tiles

Persian Tiles

Design

Kiln

Raw Material

\section{ABSTRACT}

Kashi tiles are the traditional ceramic tiles of Pakistan. They have been produced in Pakistan (previously India) for centuries now; they were brought to India by Persian potters of city Kashan. This paper is in effort to remedy the regrettable absence of documentation of Kashi tiles in the heritage of Muslim enamel tiles. The purpose was to investigate the connection between Persian and Kashi tiles and analyze their similarities and differences. The hypothesis is investigated by literature review of different books and research papers and by interviewing Kashikar of Pakistan about their practices and they were studied and compared. The results and conclusions of this study are the ceramists have very limited knowledge and have refused to accept any new idea due to their loyalty to the craft. They believed in keeping the original recipe intact and have firmly refused to experiment and explore. These tiles were never exactly same to Seljuk blue and white tiles; and the forefathers of these ceramists had obviously studied their environment and experimented with local raw materials. However it is clear from the close remembrance in Design and color palate of these crafts that the original migrated potters were definitely recreating the blue and white craft of Persia, that was imitation of Chinese porcelain.

This is an open access article under the CC-BY-SA license.

\section{Introduction}

Kashi is a Persian word used for all types of glazed pottery. But in Pakistan it is particularly used for a specific traditional type of tiles including brickwork and tile-mosaic work, which was produced heavily in India and Persia. Though the roots of blue and white ceramics can be traced as back as Uighurs of 8th and 9th century, but the real development happened during Karakhanid, Ghaznavid, and specially Persian Seljuk Art, Their peak of success was in the sixteen and seventeen century. (Birdwood 1884: 1)

The craft arrived at Persia in the eleventh century during Seljuk period, when Turk tribes have invaded and captures almost all of Persia. Turk-Persian influence was adopted in abundance by India under Muslim rule specially by Mughals founded in 1526. The vast influence of this age is still visible in every aspect of Pakistani heritage in language, literature, poetry, arts and craft, design, history, etc. The oldest Kashi tiled building is Dabgir Mosque build in 1588. Mosques like Shah Jahan Mosque in Thatta, that were build under Shah Jahan Mughal the emperor of the Mughal dynasty was also adored by Kashi tiles and are direct testimony towards the link between the Mughals and the journey of Kashi tiles in India (Now Pakistan) (Figure 1). Mughals were of Persian heritage it is natural that Persian artisans and craftsmen along with people of different walks of life moved to Hindustan. However these tiles in Pakistan were popularly used in mosques, shrines and tombs of holy personalities left them strictly for religious purposes. However over time these building have extended to museums, Libraries and universities but the change is very recent and it is 
only because these places are considered very respectable however Persians were a little more flexible with the usage as it can be seen in buildings like palaces and public baths (Figure 2) (Hugh Chisholm and Franklin Hooper 1911: 490).

In Persia, to organize a ceramic workshop a strict chain of command was part of procedure, these workshops were headed by an "ustad" or "master" who deliberately kept a few students and jealously hid the knowledge of ceramics. Those apprentices were mostly members of his own family working under him. Once these apprentices finished their training, a few went off to start their own potteries in other locations while others remained in the workshop carrying on the tradition within the family. And these families are still present in Pakistan working, still working with the craft of Kashi, though they do not enjoy the same wealth and distinction, but it is very interesting how they have managed to keep the craft strictly within family after all these centuries. By keeping the craft within the family-run industry system, potters tried to preserve this skill in its original form (Porter 1995:12) (Farida M Said 2015).

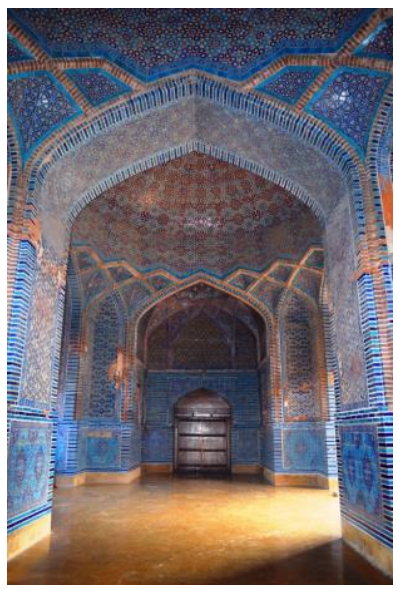

Fig. 1.Shah Jahan Mosque, Thatta, Pakistan 1647 (Lambourn 2003)

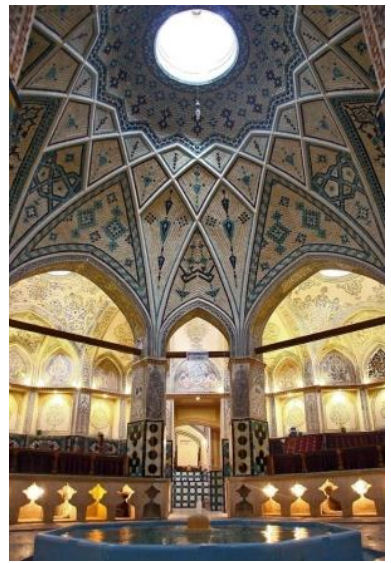

Fig. 2. Sultan Amir Ahmad Bathhouse, Kashan Iran, 1778, year or renovation (Garmroudi 2013)

\section{Method}

It is a popular claim among the Pakistani Kashi tile makers that the Kashi tiles have seen no change since they came from Persia in sixteenth century under Mughal dynasty. As the motive of this research was to analyze the old Persian tiles with current Pakistani Kashi tiles to verify the claim that the craft has indeed been untouched and unchanged since then. The author has visited every single Kashi centre in Nassarpur and Hala as they are the hub of Kashikari in Pakistan, on 11th February 2017. The total number of Kashi centers in Hala were six and in Nassarpur the number was five. To investigate and understand the method involved in the production of this craft the author engaged in discussion with multiple craftsmen.

The author has analyzed both the notes from 16th century quoted in various books along with studying different monuments and their history in order to learn about the craft the design of Kashi 
tiles were specially inspired by Persian heritage and the kilns used were also same and compared it with the currently used raw materials in Pakistan. The basis of interpretation, validation and conclusion of this paper is the analysis done by deeper study of scientific chemical reactions involved in both tiles, by comparing the raw materials of Kashan tiles of Persia with Kashi tiles of Pakistan. It is understandable by the resemblance of both tiles clearly the Persian migrated craftsmen were trying to recreate the same craft and therefore the replaced raw materials are chosen specially to achieve the identical visual affect of blue white tiles with transparent shining glaze.

\section{Result and Discussion}

The claim made by Kashi families is that the craft is $100 \%$ identical to Persian Seljuk ceramics craft practiced centuries ago, that no change has occurred since then, however the claim can be challenged easily because the Kashi tiles in Pakistan are of two types and one of them doesn't belong from Persia. First is the 'blue and white Kashi', and the second is 'Murdasang', which is brown in color and has different glaze. Murdasang is very different from Persian tiles, in fact it is a style developed by Kashikar families in Pakistan. Usually blue and white Kashi and Murdasang are arranged in mosaic together to make symmetrical designs but they are prepared from completely different glazes and are fired separately (Figure 3) (Doudpota, n.d:70) .

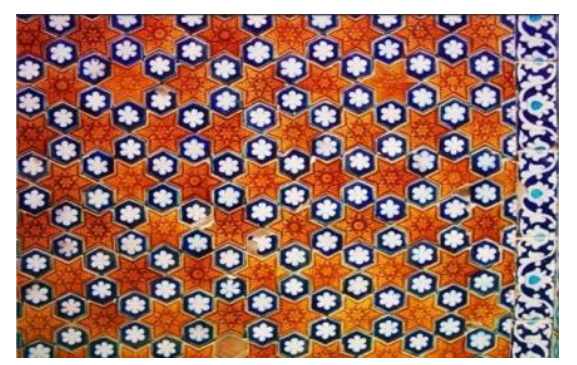

Fig. 3. Jamia Mosque Nassarpur (Pakistan)

\subsection{Types of Designs on Both Kashi Tiles and Persian Tiles}

\subsubsection{Floral Design}

Floral designing was popularly used by both Kashikars of Pakistan and Persia. Naturalism of flowers was remarkable and at the same time designing has symmetry. Richness of space, color and light were highly regarded. It aimed to be better than reality: patterned, symmetrical, and designed with perfection far beyond anything natural. And these designs became more popular in tile designing (Figure 4) (Aziz $2004: 110$ ).

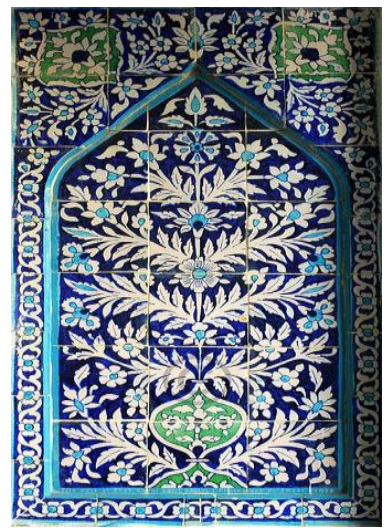

Fig. 4. Shrine of Shah Abdul Latif Bhittai, Bhit Shah (Pakistan) (1764) (Lashari and Awan 2014)

\subsubsection{Calligraphy}

Both Ceramists in Kashan and Kashikar of Pakistan has a deep affection and appreciation of Calligraphy. Calligraphy in Arabic refers to "handasat al-khatt" ", "lines" mean "letter" or

\footnotetext{
${ }^{1}$ Geometry of lines
} 
"writing".Since the rise of Islam, calligraphy has been a major art form. Numerous khatt (writing styles) have been introduced and were used actively in architecture in Kashi tiles designs, with styles such asRihani, Thulth, Thuluth jail, Ruqa'h, Naskhi, dewani, etc. The language of calligraphy in scripture is either Persian or Arabic in both Persia and Pakistan, even though both languages do not reside in the country of Pakistan. Arabic is usually the Quranic verse are quoted frequently; however Persian calligraphy was used are purely secular subjects. Other general texts were either regarding the architecture itself, religious tags, traditional proverbs, or general good wishes. Usually blue letters were used against a white background (Figure 5) (Aziz 2004: 11) (El-Said and Parman 1976: $34)$.

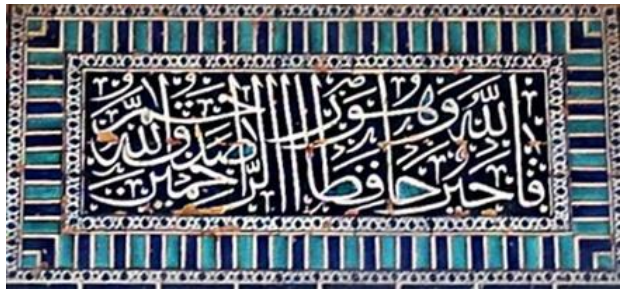

Fig. 5. Tomb of Prince Sultan Ibrahim bin Mirza Muhammad Isa Tarkhan, Makli Hill Thatha (1556-1592)

(Qazi 2010)

\subsubsection{Geometric Design}

Geometry plays a very vital and significant role in both Persia (seljuk period) and Pakistan and the similarities are undeniable. The decoration of exteriors and the interiors of Islamic buildings and monuments was predominantly non-representational and, in the case of mosques, invariably so. Calligraphy and geometric designs were used to convey an effect appropriate to the purpose of the buildings. The concepts and the method with which the architect and the designer worked were the same, enabling them to achieve a totality of purpose in artistic creation. Even though the geometric patterns, consisted of, or were generated from, such simple forms as the circle and the square, they were combined, duplicated, interlaced, and arranged in intricate combinations, becoming one of the most distinguishing features of Islamic art. Geometric ornamentation in Islamic art suggests a remarkable amount of freedom: in its repetition and complexity, it offers the possibility of infinite growth and can accommodate the incorporation of other types of ornamentation as well (Figure 6) (El-Said and Parman 1976: 30).

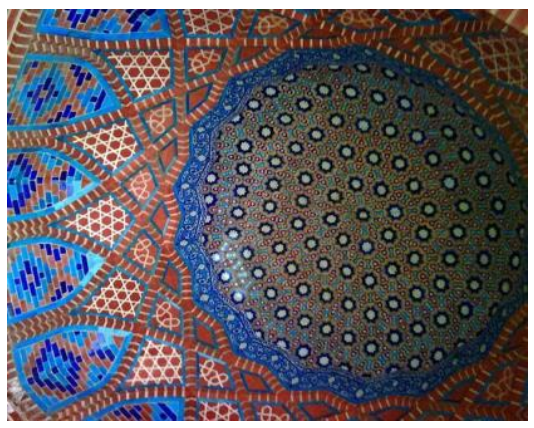

Fig. 6. Shah Jahan Mosque, Thatta (Pakistan).(1647) (Qazi 2010)

\subsubsection{Figurative Design}

Figurative designs have never been part of Kashi tiles in its long history, because the Muslim faith revolves around the concept of one God with no figurative illustrations and strict prohibition on idol worshiping, the craftsmen focused on producing variety of designs in tiles with no figures ${ }^{2}$ because the kashi tiles were mainly produced for mosques in Persia and later in India. They used natural elements like the basic shapes of flora and fauna and wrote Quranic verses in beautiful calligraphies. However, the Persian craftsmen took the liberty to make figurines in their ceramics when they produced it for non-religious building but they were not many in number (Figure 7) (Yusuf 2012: 98).

\footnotetext{
${ }^{2}$ Animals, humans or supernatural
} 


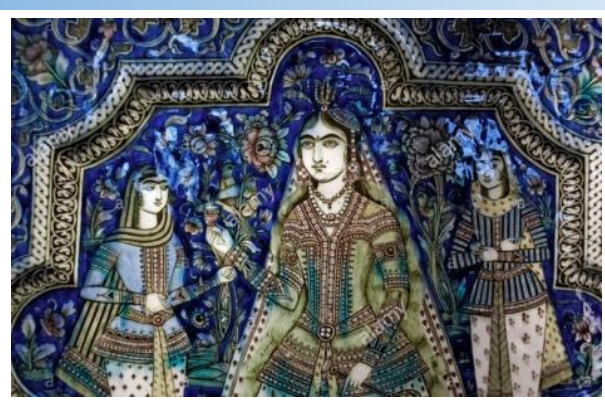

Fig. 7. Persian Ceramics Tile, Brussels Museum, Belgium (Ivan Vdovin 2010)

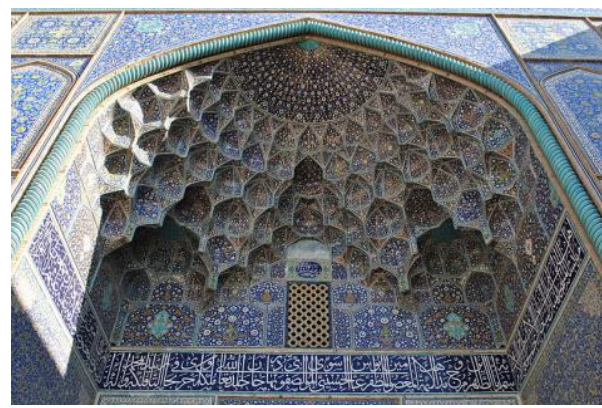

Fig. 8. The Shah Mosque, Isfahan, Iran 1629 (Grabar 1990)

\subsection{Comparison of Kilns}

The kiln used in the Pakistan is identical to what was used in Seljuk Period in Kashan, Persia.The Kashi workers still use the same wooden traditional kiln technology that was brought to this region centuries ago. during my research, I found have come across only one center names NITA crafts centre to have a gas kiln, the center itself is not more than 5 years old. The duration of firing is twelve hours, just as it was for the Persians. As most of the workers struggle with financial problems and availability of wood, quality is another issue for them.

They have had to make compromises with their kiln firing process. It is one of the factors among the others for the decline in the quality of their work. The old masters in Persia didn't have any means to measure the exact temperature inside their kiln, and this practice stubbornly continues with Pakistani Kashikars.

These kilns do not have any means to measure the temperature, remaining outdated like their ancestral counterparts. But the workers still claim to fire murdasang on $950^{\circ} \mathrm{C}$ and transparent white glaze on $1050^{\circ} \mathrm{C}$. Some of the Kashi workers confided that they fire both bodies in one kiln and opt for temperature $950{ }^{\circ} \mathrm{C}$, yet another compromise on the quality of work (Figure 9) (Doudpota, n.d: 70).

The kilns are up draught kilns, two chambered kiln with either round or oval shape. The upper and lower chamber is separated by perforated barer. The firebox is in the lower chamber. The heat passes through the holes of the perforated wall in between the two chambers. Pottery is kept in the upper chamber, placed and replaced from the domed roof of the kiln. Abu'l Qasim, historian of the Mughal court and the member of the Abu Tahir family of potters, described the Kiln in a manuscript dated AD 1301, which states:

"This is like high tower and inside has upon row of earthenware pegs, fitted into holes in the wall. The vessels are placed on them and fired for twelve hours with the hot even fire, with this stipulation that no wood be put on until the smoking has stopped. The vessels are removed from the kiln after week." (Bennett 2005: 55). 


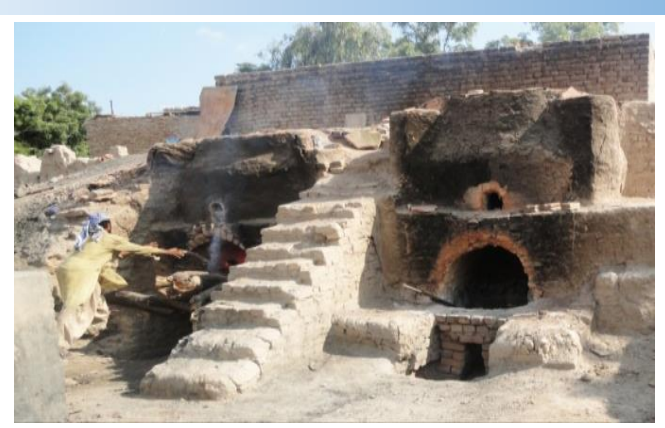

Fig. 9. Kiln at Nassarpur, Pakistan (oldest Kashi tile center in Pakistan)

\subsection{Comparison of Glazes}

\subsubsection{Persian Glaze}

As per described by Abu'l-A Qasim treatise of 701AH/AD1301 the 'fritware'. The stone paste was prepared with ten parts ground quartz mixed with one part glaze frit and one part fine white clay. The ground quartz was obtained from pebbles collected from the dry river beds or from sand. The glaze frit, and culminated soda plant is heated to the point where it melts into clear glass which serves to hold the ground. The third important element was pure white clay which often had to be brought from far field. The composition of the glaze is best described by Oliver Watson: "the glaze is formed of a roughly equal mixture of ground parts and the ashes of desert plants which contains a very high proportion of alkaline salts. These act as a flux and cause the quartz to vitrify at a manageable temperature. The two alone will produce a transparent glaze".

The ceramic wares were covered with a thin layer of white slip. This had a comparable composition to the frit ware paste used for the clay body. But the ingredients were chosen with more delicacy and care, to avoid any iron impurities. Iron impurities are responsible for discoloring white surface. Tragacanth gum was used as an organic binder in Kashan. Whereas the Kashi Tile makers in Pakistan use wheat flour diluted by water in paste form and add it into the glaze. It serves as glue between the glaze and clay body (Porter 2005:15) (Porter 1995:24) (Chapman, Caroline 2014: 333).

\subsubsection{Kashi Glaze}

The Transparent Glaze frit contains 25\% read lead, 25\% Soda Ash, 25\% Silica sand and 25\% Borax. Whereas the Murdasang contains $80 \%$ Red lead, 20\% Silica sand and $10 \%$ either iron oxide when brown color is required or $10 \%$ copper oxide for green color. However as Murdasang is clearly not a craft developed in Persia, only blue and white tile work of Pakistan and Persia is compared below (Doudpota, n.d: 67).

\subsection{Comparisons between Kashi Glaze Materials and Persian Glaze Materials.}

The results of my analysis are illustrated in the tables below. I have compared raw materials of both glazes and discussed them in detail individually.

\subsubsection{Raw Materials with Similar Characteristics but Different Chemical Properties}

Following materials were replaced from the original Persian recipe. Even though the desired result is the same, the chemistry has changed (Table 1).

Table 1. Comparisons between Kashi Glaze Materials and Persian Glaze Materials

\begin{tabular}{|c|c|}
\hline Persian tiles & Kashi Tiles \\
\hline White Tin Oxide & Calcium Carbonate (Limestone) \\
\hline $\mathrm{SnO}_{2}$ & $\mathrm{CaCO}_{3}$ \\
\hline Characteristic: Used as white coat of engobe. 3 & Characteristic: Used as white coat of engobe. \\
\hline Potash (Potassium Carbonate) & Borax \\
\hline $\begin{array}{c}\mathrm{K}_{2} \mathrm{CO}_{3} \\
\text { Characteristic. }\end{array}$ & $\mathrm{Na}_{2} \mathrm{~B}_{4} \mathrm{O}_{7} \cdot 10 \mathrm{H}_{2} \mathrm{O}$ or $\mathrm{Na}_{2} \mathrm{O}_{2} 2 \mathrm{~B}_{2} \mathrm{O}_{3} .10 \mathrm{H}_{2} \mathrm{O}$ \\
\hline
\end{tabular}

\footnotetext{
${ }^{3}$ Engobe is a process of coating a clay body with another liquid body to change its surface color to white of lighter tones.
} 


\subsubsection{White Tin Oxide (Engobe in Persian Tiles)}

Tin oxide was used as engobe by Kashan ceramists. It gives elasticity to the glaze. The metal oxides were the colorants used and effectively their color enhances against tin oxide. They were applied on unfired surface (Hamer, Frank 1997: 359).

\subsubsection{Calcium Carbonate (Limestone)(Engobe in Kashi tiles)}

Limestone is calcinated ${ }^{4}$ and grinded and used as the engobe for Kashi tiles. Limestone is naturally white in color. It decomposes at $825^{\circ} \mathrm{C}\left(1517^{\circ} \mathrm{F}\right)$ and provides calcium oxide and carbon dioxide. The carbon dioxide evaporates and the clay and glaze body is left with calcium oxide (Hamer, Frank 1997: 42).

$$
\mathrm{CaCO}_{3} \stackrel{825^{\circ} \mathrm{C}}{\longrightarrow} \mathrm{CaO}+\mathrm{CO}_{2} \uparrow \text {. }
$$

\subsubsection{Potash (Potassium Carbonate; $\mathrm{K}_{2} \mathrm{CO}_{3}$ ): Pearl Ash}

Soda Ash and Potash was combined with stone paste for the glaze recipe in Persia and was a very important ingredient. Now the use of Potash is completely missing from Kashi tiles in Pakistan. Potash is a highly soluble salt and used in frits and glass. When fired it decomposes into potassium oxide and carbon dioxide.

$$
\mathrm{K}_{2} \mathrm{CO}_{3} \stackrel{900^{\circ} \mathrm{C}}{\longrightarrow} \mathrm{K}_{2} \mathrm{O}+\mathrm{CO}_{2} \uparrow
$$

Wood ash was the main source of potassium carbonate. Wood ash is the inorganic residue after the combustion of the organic structure. originally wood was used but later other vegetables were also added into this category. Wood ashes contain $90 \%$ alkaline fluxes. The remaining is silica and phosphorus oxide. It could also be termed as natural glaze because upon heating, it can turn glassy like a glaze (Hamer, Frank 1997: 260).

\subsubsection{Borax: $\mathrm{Na}_{2} \mathrm{~B}_{4} \mathrm{O}_{7} \cdot 10 \mathrm{H}_{2} \mathrm{O}$ or $\mathrm{Na}_{2} \mathrm{O} .2 \mathrm{~B}_{2} \mathrm{O}_{3} \cdot 10 \mathrm{H}_{2} \mathrm{O}$}

Borax is a crystalline mineral, the main source of boron oxide with sodium oxide. It is used in low-melting glaze frits. When Borax is heated, it decomposes into sodium Meta borate, boron oxide and water.

$$
\mathrm{Na}_{2} \mathrm{~B}_{4} \mathrm{O}_{7} \cdot 10 \mathrm{H}_{2} \mathrm{O} \rightarrow 2 \mathrm{NaBO}_{2}, \mathrm{~B}_{2} \mathrm{O}_{3}+10 \mathrm{H}_{2} \mathrm{O} \uparrow
$$

\subsubsection{Borax Frit: A frit made from borax and silica (or silicate)}

Borax is a main ingredient for Blue and White Kashi tiles. It provides sodium oxide and boron oxide. Sodium oxide and Boron are both fluxes; but the boron oxide is a glass former as well. Both flux silica at a low temperature, usually a molten glass is produced in result as frit. It is easily ground into powder. There are many possible unity formulae for the borax frit (Hamer, Frank 1997: 32) The simplest is

$$
\mathrm{Na}_{2} \mathrm{O} .2 \mathrm{~B}_{2} \mathrm{O}_{3} \cdot 3 \mathrm{SiO}_{2} \text {. }
$$

\subsection{Different Raw Materials with Identical Chemical Properties}

Following are the materials used in Kashi and Persian glazes that have very different physical properties but up to $99 \%$ chemical composition is same (Table 2). Although they are gained from very different sources, they achieve same results after being fired.

Table 2. Different Raw Materials with Identical Chemical Properties

\begin{tabular}{cc}
\hline Persian Tiles & Kashi Tiles \\
\hline Quartz $\mathrm{SiO}_{2}$ & Silica Sand \\
Source: Quartz pebbles & $\mathrm{SiO}_{2}$ \\
\hline Plant Ash & Source: Red Sand /Quartz sand \\
$\mathrm{Na}_{2} \mathrm{CO}_{3}$ & Soda Ash \\
Source: Sea plants & $\mathrm{Na}_{2} \mathrm{CO}_{3}$ \\
\end{tabular}

\footnotetext{
${ }^{4}$ Heating to high temperatures in air or oxygen.
} 


\subsubsection{Quartz $\left(\mathrm{SiO}_{2}\right)$}

Quartz is the main component of Persian glaze mentioned by Abu'lQasim. It is popularly known as milky quartz and crystal quartz. Quartz is basically a term for the primary phase of Silica. Physical properties of Quartz rock are its opaque white, greasy-looking body. It is sharply angular rock. They usually occur as veins in other rocks and hardly survive as white pebbles, which are often included in conglomerate rocks. Usually Crystal quartz are larger in size, they are visible to the naked eyes. They are perfectly clear and colorless but usually look white from the distance. Crystal and Rock quartz both have the hardness of number 7 on Moh's scale. But interestingly, Silica can also be found naturally as soft sand. It is usually known as Silica Sand or Quartz Sand (Hamer, Frank 1997: 271).

\subsubsection{Silica Sand $\left(\mathrm{SiO}_{2}\right)$}

Silica sand is the most important raw material used in both Kashi tile glazes. It is interesting to note that quartz is $99 \%$ silica and 1\% impurities, whereas Silica sand is 100\% silica. During firing process, they both give identical results. The natural form of both materials is very different though the chemical properties are $99 \%$ similar. Silica provide the glossiness? in glazes, raises the melting point, and prevents abrasion. Usually Kashikars bring silica sand from Sehwar ${ }^{5}$. Kashani ceramists also collected Quartz pebbles from their surroundings. The Kashikars and Kashani potters used Quartz and Silica sand to obtain Silica glass (Hamer, Frank 1997: 303-304).

\subsubsection{Plant Ash: $\left(\mathrm{Na}_{2} \mathrm{CO}_{3}\right)$ Sodium Carbonate}

Sea plants yield sodium carbonate upon being fired. Since the sea water contains sodium salts, it is absorbed by the plants in sea. The chemical reaction is identical to Soda ash. The Potters of Persia used Plant ash because in thirteenth century other sources were not discovered. With time, Plant ash was replaced by Soda Ash, but the results would be similar (Hamer, Frank 1997: 320).

\subsubsection{Soda Ash: $\left(\mathrm{Na}_{2} \mathrm{CO}_{3}\right)$ Culminated Soda Plant}

Soda ash is another ingredient for Blue and White Kashi tiles. Soda Ash also known as Sodium Carbonate $\left(\mathrm{Na}_{2} \mathrm{CO}_{3}\right)$ was earlier obtained by the ashes of burnt sea plants. However nowadays the process of producing Sodium carbonate has changed. It is now created by Solvay process, by Sodium Chloride $(\mathrm{NaCl})$. Soda ash can only be used in frits because it is highly soluble. After the discovery of LeBlanc and Solvay processes in eighteenth and nineteenth centuries, soda ash was obtained from salt rock and sea water, when earlier it was obtained from salt marsh plants and seaweeds. Hence, it was named Soda ash. Surprisingly, Kashikars have adopted this change, one of the rare occurrences in the long history of Kashikari (Hamer, Frank 1997: 318).

\subsection{Raw Material Used for Different Purposes}

Following is the raw material that was used differently by the Kashi and Persian ceramists (Table $3)$.

Table 3. Raw Material Used for Different Purposes

\begin{tabular}{cc}
\hline Persian Tiles & Kashi Tiles \\
\hline White clay & White clay \\
Calcium Oxide (Lime) & Calcium Oxide (Lime) \\
CaO & CaO \\
Usage: Added as glaze ingredient. & Usage: Used as designing colorant in Murdasung and used \\
& as engobe. \\
\hline
\end{tabular}

\subsubsection{White Clay: Calcium Oxide (Lime), $\mathrm{CaO}$}

The pure oxide $(\mathrm{CaO})$ is also called quicklime. It reacts with water, combining with it to produce calcium hydro oxide, called slaked lime $\left(\mathrm{Ca}(\mathrm{OH})_{2}\right)$. Calcium oxide is therefore introduced into the bodies and glazes in the insoluble form of the carbonate $\left(\mathrm{CaCO}_{3}\right)$ and the borate $\left(\mathrm{Ca}\left(\mathrm{BO}_{2}\right)_{2}\right)$. However the Kashikar use it as colorant for Murdasang. They painted designs on the clay body under the translucent colored glaze. Calcium oxide is a clay body that can be found naturally in different parts of the world with different colors. It is not as white as Limestone, therefore it is not used independently as engobe in White and Blue tiles. But it is called red-slip and white-slip depending on its color that is determined by the amount of iron impurity in it. A readily available

${ }^{5}$ a small town near Nassarpur and Hala 
and extremely useful body and glaze material, it is used as filler in low-temperature bodies and glazes; and as a flux in high-temperature glazes. Large amounts encourage crystalline growth during cooling. It is the white body mentioned in Stone paste recipe by Abu'l Qasim and was used as an ingredient in Persian glaze (Hamer, Frank 1997: 43).

\subsection{Same Materials Used for Identical Purposes in Kashi and Seljuk Tiles}

Following are the raw materials used in Kashikari and Persian tiles for same purposes (Table 4).

Table 4. Same Materials Used for Identical Purposes in Kashi and Seljuk Tiles

\begin{tabular}{cc}
\hline Red Lead: $\mathrm{Pb}_{3} \mathrm{O}_{4}:$ & Usage: Glaze material (fritted) \\
\hline Cobalt Oxide: $\mathrm{CoO}$ or $\mathrm{CoO}_{2}, \mathrm{Co}_{2} \mathrm{O}_{3}, \mathrm{Co}_{3} \mathrm{O}_{4}$ & $\begin{array}{c}\text { Cobalt blue colorant } \\
\text { Usage: Designing }\end{array}$ \\
\hline Copper oxides: $(\mathrm{CuO})$ & $\begin{array}{c}\text { Turquoise and Green Colorant } \\
\text { Usage: Designing }\end{array}$ \\
\hline
\end{tabular}

\subsubsection{Red Lead: $\mathrm{Pb}_{3} \mathrm{O}_{4}$ (Persian glaze frit) Lead Oxide $\mathrm{PbO}$}

Red lead also known as Lead trioxide decomposes and becomes lead oxide ( $\mathrm{PbO})$, when heated. It is a very adaptable and useful glaze flux. Red Lead fluxes at a low temperature of $500^{\circ} \mathrm{C}\left(932^{\circ} \mathrm{F}\right)$, it matures at $800^{\circ} \mathrm{C}\left(1472^{\circ} \mathrm{F}\right)$. It is a main ingredient for both Murdasang and White and Blue Kashi tiles. Usually it's preferred to be used in fritted form because its efficiency extends and effectively reduces its toxicity. Lead and Lead compounds are cumulative poison. Abu'lQasim didn't disclose the ingredients of mentioned glaze frit in his recipe, but it is quite possible that the glaze frit mentioned is Lead oxide because by the end of twelfth century and beginning of thirteenth century lead glaze was very popular with Persians. They were using it in different type of wares (Hamer, Frank 1997: 282) (Cooper, Emmanuel 1998: 41).

\subsubsection{Cobalt Oxide: $\mathrm{CoO}$ or $\mathrm{CoO}_{2}, \mathrm{Co}_{2} \mathrm{O}_{3}, \mathrm{Co}_{3} \mathrm{O}_{4}$}

In the early period, only cobalt blue was used for decoration by Persian potters. Cobalt blue was easily available at the village of Qamsar in Persia, near the town of Kashan as mentioned by Abu'lQasim in his treatise. Kashikar in Pakistan also use Cobalt oxide as the colorant for cobalt blue. It is also the color they use to draw outlines of their designs; in some design it is used as filler as well. The cobalt oxide is the major colorant for blue in Ceramics. It has been the most popular colorant in ceramics for nearly 2000 years. Cobalt blue is the strongest and richest colorant in ceramics (Chappell 1977: 419).

\subsubsection{Copper oxides: $(\mathrm{CuO})$}

In 1520 turquoise (copper oxide) was introduced. Other colors such as, green, grey and black, the distinct bright red was introduced in around 1560 in Persia. The knowledge must have been shared with the Kashikars here as well because the use of Copper oxide is as old as the craft itself.

Greens of grayish nature is obtained if copper oxide if used with lead glaze, turquoise in alkaline glazes, yellow green in potash. The solubility of lead glaze increases when copper oxide is used. It is a very versatile oxide. Potters used different chemical reactions to get different color results from Copper oxide (Chappell 1977: 419).

\section{Conclusion}

Kashi tiles were brought to India from Persia during Mughal dynasty. The credit of spreading this craft belongs to the Muslim rulers who were determined to construct their patronage through art and architecture. This paper is in effort to remedy the regrettable absence of documentation of Kashi tiles in the heritage of Muslim enamel tiles. The purpose was to investigate the connection between Persian and Kashi tiles and analyze their similarities and differences. In my research I have discovered that even if the equipment, procedure and design are highly similar, the chemistry involved has changed drastically. Four out of five main ingredients of the glaze are replaced though both colorants used in these tiles are same but the glaze essentially has changed up to $80 \%$. Which makes Kashikar families' claim to be invalid as it is clear through this research that the recipe has indeed changed drastically. 


\section{Acknowledgment}

This research paper wouldn't have been possible without the guidance, patience and support from following people:

Mr. Bhai Khan Shar, Director Center of excellence in Art and Design. Thank you, Sir for literally pushing me to complete this paper, I am very grateful for your guidance and interest in this paper. It gave me the confidence to finish it.

Mr. Ghulam Hyder Doudpota, Chairman NITA crafts Development Multipurpose co-operative Society Nasarpur. Thank you Sir I seriously would have given up on this paper if you hadn't helped me with my work, I have no words to express my gratitude.

Mr. Hassan Kashikar, Thanks to your invitation to your family Kashi center all those years ago, it sparked the interest for this journey and I am grateful for your supportive input in this paper.

My parents, Mr. Wazir Ali Bhayo Mrs.Marium Bhayo,Thank you for your support and understanding. My friend Dania Zafar, Thank you for all those discussions and tips to improve my work. I really appreciate it.

My sisters Sumbal Wazir Ali and Samra Haseeb, Thank you for your support and help.

\section{References}

Aziz, Khursheed Kamal. 2004. The Meaning of Islamic Art. Lahore: Al-Faisal.

Bennett, James. 2005. Crescent Moon. Adelaide: Art Gallery of South Australia.

Birdwood, George Christopher Molesworth. 1884. The Industrial Arts of India. Chapman and Hall.

Chapman, Caroline, and Moya Carey. 2014. The Illustrated Encyclopedia Of Islamic Art And Architecture. 1st Ed. London: Lorenz Books.

Chappell, James. 1977. The Potter's Complete Book Of Clay And Glazes. 1st Ed. New York: Watson-Guptill.

Cooper, Emmanuel, and Eileen Lewenstein. 1998. Clays And Glazes. London: Craftsmen Potters Association of Great Britain.

Doudpota, Ghulam Hyder. n.d. "Revival of Classical Art of Kashikari."

El-Said, Issam, and Aylcse Parman. 1976. Geometric Concepts in Islamic Art. Dale Seymour Pubn.

Farida M Said. 2015. "Tradition of the Tile.” Herald. 2015. https://herald.dawn.com/news/1152933.

Garmroudi, Aida Alizadeh. 2013. "An Investigation on Interior Spaces Related to Ornamentations (Based on Material) of Selected Spatial Houses of Kashan (IRAN) in QAJAR Period (19th)." Eastern Mediterranean University (EMU)-Do $\{\backslash \mathrm{u}\{\mathrm{g}\}\} \mathrm{u}$ Akdeniz Üniversitesi (DAÜ).

Grabar, Oleg. 1990. The Great Mosque of Isfahan. Tauris.

Hamer, Frank, and Janet Hamer. 1997. The Potter's Dictionary Of Materials And Techniques. 1st Ed. London: A \& C Black.

Hugh Chisholm and Franklin Hooper. 1911. 11th Edition of the Encyclopedia Britannica. London and New York: Horace Everett Hooper.

Ivan Vdovin. 2010. “Old Iranian Art, Museum, Brussels, Belgium.” Alamy. 2010. https://www.alamy.com/stock-photo-old-iranian-art-museum-brussels-belgium29915212.html.

Lambourn, Elizabeth. 2003. "Of Jewels and Horses: The Career and Patronage of an Iranian Merchant Under Shah Jahan.” Iranian Studies 36 (2): 213-58. 
Lashari, Mubarak Ali, and Muhammad Safeer Awan. 2014. "The Concept of Love: A Comparative Study of Maulana Rumi and Shah Abdul Latif Bhittai.” European Scientific Journal, ESJ 10 (10).

Porter, Venetia. 1995. Islamic Tiles. British Museum Press.

2005. Islamic Tiles. 1st Ed. London: British Museum Press.

Qazi, Muhammad Naeem. 2010. "Tarkhan Dynasty at Makli Hill, Thatta (Pakistan): History and Architecture of the Selected Monuments." University of Peshawar.

Yusuf, Danish. 2012. Encyclopaedia of Islamic Art And Architecture, 1st Ed. New Delhi: Random Publications. 